\title{
EFFECT OF DIETARY PROTEIN ON THE BIOSYNTHESIS OF INOSITOL IN RAT TESTES
}

\author{
GHAFOORUNISSA \\ National Institute of Nutrition, Indian Council of Medical Research, \\ Hyderabad-500007, India
}

(Received 30th May 1974)

\begin{abstract}
Summary. The presence of inositol in high concentrations in semen and the male reproductive organs of mammals suggests that it may have an important rôle in male reproduction. The present study is an attempt to investigate the effect of dietary protein restriction in the male rat on inositol synthesis in the testes and on the concentration of inositol in some of the accessory sex organs. The results show that marginal protein deficiency does not alter either the biosynthesis of inositol or inositol concentration in the testis, epididymis or seminal vesicles.
\end{abstract}

\section{INTRODUCTION}

Many studies on the effect of undernutrition and malnutrition on the reproductive performance of the female have been carried out in experimental animals (Nelson, 1959; Callard \& Leathem, 1970; Stewart \& Sheppard, 1971; Turner, 1972; Widdowson \& Cowen, 1972) and in man (Smith, 1947; Gopalan, 1962; Iyengar, 1972), but similar studies on the male are scanty. One of the reasons for this is the inadequate understanding of male reproductive physiology and of the parameters by which reproductive performance can be measured. Semen and other secretions of the male reproductive tract are found to be rich in substances like fructose, citric acid and inositol (Melampy \& Mason, 1957; Mann, 1964), but the functional significance of these constituents is not entirely clear. The presence of inositol in semen in concentrations 100-fold higher than in blood (Hartree, 1957; Nixon, 1964; Setchell, Dawson \& White, 1968) suggests that it may have an important rôle in male reproduction. The present study is an attempt to investigate the effect of dietary protein restriction on inositol synthesis in the testis and on the concentration of inositol in some of the male accessory sex organs.

\section{MATERIALS AND METHODS}

Sixty male albino rats aged 24 to 28 days and weighing about $45 \mathrm{~g}$ were allocated to one of three groups. The twelve animals in Group I received an $18 \%$ protein diet and served as the controls. Groups II and III each consisted of twenty-four animals which received a $7 \%$ protein diet. Animals in Groups I and II received $25 \mathrm{mg}$ inositol/100 $\mathrm{g}$ diet, as suggested by the National Academy

c 
of Sciences, National Research Council, U.S.A. (Campbell, 1963). The detailed composition of the diet is given in Table 1. Inositol was not added to the diet of rats in Group III; analysis showed that the diet contained $0.40 \mathrm{mg}$ inositol $/ 100 \mathrm{~g}$ diet.

Table 1. The composition $(\mathrm{g} / 100 \mathrm{~g})$ of the experimental diets fed to male rats

\begin{tabular}{|c|c|c|c|}
\hline Constituent & Diet $I$ & Diet II & Diet III \\
\hline $\begin{array}{l}\text { Casein } \\
\text { Corn starch } \\
\text { Peanut oil } \\
\text { Salt mixture* } \\
\text { Vitamin mixture† without inositol } \\
\text { L-Cystine } \\
\text { Inositol } \\
\text { Proteinf }\end{array}$ & $\begin{array}{l}22 \cdot 0 \\
67 \cdot 8 \\
5 \cdot 0 \\
4 \cdot 0 \\
1 \cdot 0 \\
0 \cdot 200 \\
0 \cdot 025 \\
18\end{array}$ & $\begin{array}{l}8 \cdot 5 \\
81 \cdot 3 \\
5 \cdot 0 \\
4 \cdot 0 \\
1 \cdot 0 \\
0 \cdot 200 \\
0 \cdot 025 \\
7\end{array}$ & $\begin{array}{l}8 \cdot 5 \\
81 \cdot 3 \\
5 \cdot 0 \\
4 \cdot 0 \\
1 \cdot 0 \\
0 \cdot 200 \\
7\end{array}$ \\
\hline
\end{tabular}

* See Horwitz (1965).

$\uparrow$ See Campbell (1963).

$\$$ The casein used contained $82 \%$ protein.

Testicular biosynthesis of inositol was measured in half the number of animals in each group after 12 weeks of feeding the respective diets and in the remaining half after 16 weeks. The animals were killed by cervical dislocation, and the testes were quickly dissected out and kept on ice. The seminal vesicles and epididymides of the animals killed after 16 weeks were dissected out separately, freeze dried and stored at $-20^{\circ} \mathrm{C}$ until analysis.

The testes were immediately homogenized in $0.154 \mathrm{M}-\mathrm{KCl}$ in a glass-teflon homogenizer and centrifuged at $100,000 \mathrm{~g}$ for $1 \mathrm{hr}$. In the supernatant fraction thus obtained, inositol biosynthesis was measured as the conversion of $\left[\mathrm{U}-{ }^{14} \mathrm{C}\right]-$ glucose-6-phosphate([U- $\left.{ }^{14} \mathrm{C}\right]$ glucose-6-phosphate, sodium salt, $230 \mathrm{mCi} / \mathrm{mmol}$ : BARC, India) into free $\left[{ }^{14} \mathrm{C}\right]$ inositol. The assay was carried out as described by Eisenberg \& Bolden (1965) with certain modifications. The enzyme was dialysed for $1 \mathrm{hr}$ against reduced glutathione in tris-acetate buffer, $0.05 \mathrm{M}$, $\mathrm{pH} 7 \cdot 4$. The ratio of glucose-6-phosphate: $\mathrm{NAD}: \mathrm{MgCl}_{2}$ was maintained at $1: 1: 2.5$ in the incubation mixture. The free $\left[{ }^{14} \mathrm{C}\right]$ inositol formed was separated by ascending paper chromatography in the solvent system isopropanol :pyridine : water $(9: 3: 3$ by vol.). A standard inositol was run alongside and identified by silver nitrate spray (Dittmer \& Michael, 1969). Corresponding test areas were cut out and counted in a toluene-based scintillation mixture containing 0.5\% 2,5-diphenyloxazole and 0.03\% 1,4-bis(5-phenyloxazol-2-yl) benzene. The results were expressed as nmol inositol formed $/ \mathrm{hr} / \mathrm{mg}$ protein. Protein concentration in the supernatant fraction following centrifugation of the homogenate at $100,000 \mathrm{~g}$ was measured by the method of Lowry, Rosebrough, Farr \& Randall (1951).

Free inositol was estimated in the accessory sex organs by the microbiological assay described by Barton-Wright (1972), using Schizosaccharomyces pombe (National Yeast Collection Centre, London). 


\section{RESULTS}

The results are set out in Tables 2 and 3. The body weights of rats in Groups II and III were significantly lower than those of the control group, both after 12 weeks and 16 weeks. The mean weights of the reproductive organs in the two groups were slightly lower at both times. Omission of inositol in the marginal protein diet did not per se alter either the body weights or the weights of the reproductive organs.

Table 2. Body and organ weights of male rats fed experimental diets

\begin{tabular}{|c|c|c|c|}
\hline & $\begin{array}{l}\text { Group I } \\
\text { (18\% protein } \\
\text { inositol) }\end{array}$ & $\begin{array}{c}\text { Group II } \\
(7 \% \text { protein } \\
\text { inositol })\end{array}$ & $\begin{array}{l}\text { Group III } \\
\text { (7\% protein, } \\
\text { no inositol) }\end{array}$ \\
\hline $\begin{array}{l}12 \text { weeks } \\
\text { Body weight (g) }\end{array}$ & $264.0 \pm 6 \cdot 6(6)$ & $\begin{array}{c}182 \cdot 0 \pm 5 \cdot 3(11) \\
P<0.001\end{array}$ & $\begin{array}{c}172.0 \pm 4.2(9) \\
P<0.001\end{array}$ \\
\hline Testes ( $\mathrm{g}$ ) & $2 \cdot 89 \pm 0.058(6)$ & $\begin{array}{c}2.62 \pm 0.046(11) \\
P<0.01\end{array}$ & $\begin{array}{c}2.62 \pm 0.052(9) \\
P<0.01\end{array}$ \\
\hline $\begin{array}{l}16 \text { weeks } \\
\text { Body weight (g) }\end{array}$ & $314 \cdot 0 \pm 5 \cdot 0(6)$ & $\begin{array}{c}218.0 \pm 7.4(11) \\
P<0.001\end{array}$ & $\begin{aligned} 220 \cdot 0 & \pm 4.7(11) \\
P & <0.001\end{aligned}$ \\
\hline Testes $(g)$ & $2 \cdot 99 \pm 0.079(6)$ & $\begin{array}{c}2.79 \pm 0.074(10) \\
P=0.10\end{array}$ & $\begin{array}{c}2.89 \pm 0.099(10) \\
\text { N.S. }\end{array}$ \\
\hline $\begin{array}{l}\text { Seminal vesicles } \\
\text { (mg dry weight) }\end{array}$ & $134 \cdot 8 \pm 9 \cdot 5(6)$ & $\begin{array}{c}107.3 \pm 8.4(11) \\
0.10>P>0.05\end{array}$ & $\begin{array}{c}111 \cdot 2 \pm 5.8(11) \\
P \geq 0.05\end{array}$ \\
\hline $\begin{array}{l}\text { Epididymides } \\
\text { (mg dry weight) }\end{array}$ & $220 \cdot 0 \pm 10 \cdot 0(6)$ & $\begin{array}{c}191 \cdot 8 \pm 12 \cdot 4(11) \\
\text { N.S. }\end{array}$ & $\begin{array}{c}182.7 \pm 8.2(10) \\
P<0.02\end{array}$ \\
\hline
\end{tabular}

Values are expressed as Mean \pm S.E. and those for Group II and Group III rats are compared with those in Group I. The numbers in parentheses indicate the number of animals studied.

Table 3. The effect of dietary protein on the rate of testicular inositol synthesis and on inositol content in the accessory sex organs of rats

\begin{tabular}{|c|c|c|c|}
\hline & $\begin{array}{l}\text { Group I } \\
(18 \% \text { protein } \\
\text { inositol })\end{array}$ & $\begin{array}{c}\text { Group II } \\
(7 \% \text { protein }+ \\
\text { inositol })\end{array}$ & $\begin{array}{l}\text { Group III } \\
(7 \% \text { protein, } \\
\text { no inositol })\end{array}$ \\
\hline $\begin{array}{l}\text { Protein* }(\mathrm{mg} / \mathrm{g} \text { wet wt) } \\
12 \text { weeks } \\
16 \text { weeks }\end{array}$ & $\begin{array}{r}37 \cdot 5 \pm 2 \cdot 2(6) \\
47 \cdot 71 \pm 2 \cdot 5(5)\end{array}$ & $\begin{array}{l}38.57 \pm 1.6(11) \\
48.38 \pm 0.85(10)\end{array}$ & $\begin{array}{l}39.43 \pm 2.0(9) \\
47.33 \pm 1.9(11)\end{array}$ \\
\hline $\begin{array}{l}\text { Testicular inositol synthesis } \\
\text { (nmol inositol formed/hr/mg } \\
\text { protein) } \\
12 \text { weeks } \\
16 \text { weeks }\end{array}$ & $\begin{array}{r}9.99 \pm 1.44(5) \\
11.84 \pm 1.65(5)\end{array}$ & $\begin{array}{l}11.36 \pm 0.87(11) \\
11.92 \pm 1.55(10)\end{array}$ & $\begin{array}{c}9.77 \pm 1.05(9) \\
10.49 \pm 0.66(11)\end{array}$ \\
\hline $\begin{array}{l}\text { Inositol ( } \mu \mathrm{g} / 100 \mathrm{mg} \text { dry tissue) } \\
\text { Seminal vesicles } \\
\text { Epididymides }\end{array}$ & $\begin{array}{l}492 \cdot 8 \pm 61 \cdot 1(6) \\
461 \cdot 1 \pm 79 \cdot 8(6)\end{array}$ & $\begin{array}{r}511 \cdot 42 \pm 45 \cdot 0(10) \\
397 \cdot 8 \pm 38 \cdot 7(11)\end{array}$ & $\begin{array}{l}484 \cdot 4 \pm 39 \cdot 2(10) \\
407 \cdot 6 \pm 50 \cdot 35(9)\end{array}$ \\
\hline
\end{tabular}

Values are expressed as Mean \pm S.E. Numbers in parentheses indicate the number of animals studied.

* Protein was estimated in the $100,000 \mathrm{~g}$ supernatant and values are expressed as $\mathrm{mg} / \mathrm{g}$ original wet weight.

The rate of inositol synthesis in the testes was not different in the rats in the two groups on the low protein diet compared to that in the rats in the control group (Table 3). The inositol content in the accessory sex organs was not 
significantly altered either by the level of protein or of inositol in the diet (Table 3). The protein concentration in the supernatant fraction following centrifugation of the testicular homogenates at $100,000 \mathrm{~g}$ was similar in all the three groups.

\section{DISCUSSION}

Despite the belief that malnutrition imposes severe constraints on reproduction and fertility (Gopalan \& Naidu, 1972), the highest rates of population growth in the developing world appear to be associated with areas where a majority of the people are undernourished. Evidence for this is, however, based solely on studies on the female. A significant reduction in the weight of the testes and of the accessory organs and a marked reduction in sperm count have been observed in rats reared on $5 \%$ protein diets (Leathem, 1959). Protein restriction of this order is, however, rarely encountered in human populations and the marginal protein deficiency imposed on rats in the present study more closely approximates the human situation. Protein deficiency of this order was found to bring about a significant reduction in the body weights of the animals. The reduction in weight of the reproductive organs, however, was of a lesser magnitude. This suggests that though marginal protein deficiency may impair the growth rate of young animals, it may not affect the growth of the reproductive organs to the same extent. This supports observations that testicular atrophy occurs only when the body weight is markedly reduced (Leathem, 1959).

The results of the present study also show that the capacity of the testes to synthesize inositol is not impaired in protein deficiency, although a reduced seminal output of fructose and citric acid has been reported in animals fed restricted diets (Mann, 1964). The observation that the testicular synthesis of inositol is unaltered at both times studied indicates that the enzyme systems involved in this process probably develop normally in protein deficiency and that prolonged protein deficiency probably has no adverse effect on inositol synthesis. Delays in sexual maturity and in the appearance of fructose and citric acid in semen (Mann, 1964) have been reported in under-nutrition. This suggests that inositol may have a greater significance than these two substances in male reproductive physiology. Despite the high concentrations of inositol in semen (Hartree, 1957; Nixon, 1964), its physiological rôle is obscure. A major part of seminal inositol is derived from testicular biosynthesis (Eisenberg \& Bolden, 1964). It has been suggested that inositol may be required for the normal progression of spermatogenesis or for the maturation of the spermatozoa (Eisenberg \& Bolden, 1964). Attempts to study its action in vitro (Voglmayr \& White, 1971), however, have not been helpful in understanding the significance of inositol in sperm metabolism.

The inositol content of the seminal vesicles and epididymides was unaltered in animals maintained on low protein diets. Synthesis of inositol proceeds at a much lower rate in these accessory organs than in the testes (Eisenberg \& Bolden, 1964). Since the biosynthesis of inositol in the testes of these animals was found to be unaltered, it may be assumed that the synthesis of inositol was also unchanged. 
None of the parameters studied was altered in animals which did not receive extra inositol in their diets. This may mean that dietary inositol does not contribute to the inositol in the reproductive tract, contrary to the suggestions of Melampy \& Mason (1957). On the other hand, the small amount of inositol contributed by the diet might have been sufficient for this purpose. No data are available regarding inositol requirements for the rat.

The results of the present study show that marginal protein deficiency does not alter either the biosynthesis of inositol in the testes or the inositol content of the seminal vesicles and epididymis in the rat.

\section{ACKNOWLEDGMENTS}

The author expresses her deep sense of gratitude to Dr C. Gopalan, DirectorGeneral, Indian Council of Medical Research, New Delhi, and Dr S. G. Srikantia, Deputy Director, National Institute of Nutrition, Hyderabad, for their guidance and encouragement in this study. She is indebted to Dr Kamala S. Jaya Rao for her valuable advice and untiring interest at every stage of this work. The technical assistance of Mrs Prabhavathi Paranjape is acknowledged.

\section{REFERENCES}

Barton-Wright, E. G. (1972) The microbiological assay of total and free inositol with Schizosaccharomyces pombe. Analyst, Lond. 97, 74-76.

Gallard, I. P. \& Leathem, J. H. (1970) Pregnancy maintenance in protein deficient rats. Acta endocr., Copenh. 63, 539-544.

CAmprell, J. A. (1963) Method for determination of PER and NPR. In Evaluation of Protein Quality, p. 31. Publication No. 1100 NAS-NRC, Washington, D.C.

Dittmer, J. G. \& Mrchael, A. W. (1969) Quantitative and qualitative analysis of lipid and lipid components. Meth. Enzym. 14, 482-530.

Eisengerg, F., JR \& Bolden, A. H. (1964) Reproductive tract as site of synthesis and secretion of inositol in the male rat. Nature, Lond. 202, 599-600.

Eisenderg, F., JR \& Bolden, A. H. (1965) D-Myoinositol-1-phosphate. An intermediate in the biosynthesis of inositol in the mammal. Biochem. biophys. Res. Commun. 21, 100-105.

Gopalan, C. (1962) Effect of nutrition on pregnancy and lactation. Bull. Wld Hlth Org. 26, 203-211.

Gopalan, G. \& Naidu, A. N. (1972) Nutrition and fertility. Lancet, ii, 1077-1079.

HARTREe, E. F. (1957) Inositol in seminal plasma. Biochem. 7. 66, 131-137.

HoRwitz, W. (1965) Vitamins and other nutrients: bioassay methods. In Official Methods of Analysis of the Association of Official Agricultural Chemists, 10th edn, p. 779. Association of Official Agricultural Chemists, Washington, D.G.

Iyengar, L. (1972) Influence of diet on the outcome of pregnancy in Indian women. Proc. 9th Int. Congr. Nutr., Vol. II, p. 51. Karger, Basel.

Leathem, J. H. (1959) Male reproductive system and protein nutrition. In Reproductive Physiology and Protein Nutrition, p. 12. Ed. J. H. Leathem. University Press, New Jersey.

Lowry, O. H., Rosebrough, N. J., Farr, A. L. \& Randall, R. J. (1951) Protein measurement with the Folin phenol reagent. $\mathcal{7}$. biol. Chem. 193, 265-275.

Mann, T. (1964) The Biochemistry of Semen and of the Male Reproductive Tract. Methuen, London.

Melampy, R. M. \& Mason, R. B. (1957) Androgen and the myoinositol content of male accessory organs of the rat. Proc. Soc. exp. Biol. Med. 96, 405-408.

Nezson, M. M. (1959) Relation of dietary protein to reproductive physiology in female rats. In Reproductive Physiology and Protein Nutrition, p. 2. Ed. J. H. Leathem. University Press, New Jersey.

Nixon, D. A. (1964) Inositol content of human semen. F. Reprod. Fert. 8, 419-421.

Setchell, B. P., Dawson, R. M. C. \& White, R. W. (1968) The high concentration of free myoinositol in rete testis fluid from rams. F. Reprod. Fert. 17, 219-220.

Smrre, C. A. (1947) Effect of maternal undernutrition upon newborn infants in Holland. 7. Pediat. 30, 229-243. 
Stewart, R. J. C. \& Sheppard, H. G. (1971) Protein-calorie deficiency in rats. Growth and reproduction. Br. F. Nutr. 25, 175-180.

TURNer, M. R. (1972) The effect of mild protein deficiency on fertility in rats. Nutr. Rep. Int. 5, 1-7.

VoglmaYR, J. K. \& White, I. G. (1971) Synthesis and metabolism of myoinositol in testicular and ejaculated spermatozoa of the ram. F. Reprod. Fert. 24, 29-37.

WidDowson, E. M. \& CoWEN, J. (1972) The effect of protein deficiency and calorie deficiency on the reproduction of rats. Br. $\mathcal{F}$. Nutr. 27, 85-95. 